\title{
Use of incremental levels of dehydrated olive cake in lamb diets as an alternative for grazing systems in the central dryland area in Chile: The effect on carcass traits of Suffolk Down lambs
}

\author{
Patricio Pérez ${ }^{1}$, Fernando Squella ${ }^{2}$, Claudio Aguilar ${ }^{3}$, María José Idalsoaga ${ }^{1}$, \\ Raúl Vera $^{3}$, María Sol Morales ${ }^{1}$, Mario Maino ${ }^{1}$, and Juan Ignacio Egaña ${ }^{1}$ \\ ${ }^{1}$ Facultad de Ciencias Veterinarias y Pecuarias, Universidad de Chile. Santa Rosa 11.735, La Pintana, \\ Santiago, Chile. \\ ${ }^{2}$ Instituto de Investigaciones Agropecuarias, Centro Experimental Hidango. Camino a Topocalma s/n, \\ Litueche, Región de O’Higgins, Chile. \\ ${ }^{3}$ Pontificia Universidad Católica de Chile. Av. Vicuña Mackenna 4860, San Joaquín, Santiago, Chile.
}

\begin{abstract}
P. Pérez, F. Squella, C. Aguilar, M.J. Idalsoaga, R. Vera, M.S. Morales, M. Maino, and J.I. Egaña. 2016. Use of incremental levels of dehydrated olive cake in lamb diets as alternative for grazing systems in central dryland area in Chile. The effect on carcass traits of Suffolk Down lambs. Cien. Inv. Agr. 43(2):213-221. To evaluate increased levels of dehydrated olive cake (DOC) in lambs ration on main carcass traits, 40 Suffolk Down male lambs (75.8 \pm 7.4 days of age, $24.5 \pm 3.1 \mathrm{~kg}$ live weight) were randomly assigned to one of five treatment groups. Four experimental isoenergetic and isoproteic diets were used with different levels of DOC: 0 , 16, 32 and 48\%, and an un-weaned group were kept with their mothers on grazing. Lambs had 8 days of adaptation to the diets, which were gradually introduced along with good quality alfalfa hay. During 47 days of the experiment, the lambs were confined in individual pens $\left(1.4 \mathrm{~m}^{2}\right)$ and subsequently slaughtered at $123 \pm 7$ days with an average live weight of $32.56 \pm 2.62 \mathrm{~kg}$. The live weight at slaughter (LWS), hot carcass weight, cold carcass weight, commercial yield (CY), real dressing percentage (RDP), body components weight (blood, hide, head, legs, full and empty digestive tract, and viscera), rib eye area (REA), back fat thickness (BFT), renal pelvic fat weight, and commercial cutting yield (CCY) were recorded. Additionally, the tissue composition and its ratios were calculated from the shoulder and leg. The carcass traits, CY, RDP, and REA decreased and BFT increased with increasing amounts of DOC in the diet $(\mathrm{P} \leq 0.05)$. No significant differences $(\mathrm{P}>0.05)$ in $\mathrm{CCY}$, tissue composition and ratios among the tissues of the shoulder and leg joints were detected. The addition of DOC to the diet did not affect the quality of the lamb carcass.
\end{abstract}

Key words: Lambs, olive cake, carcass traits.

\section{Introduction}

Sheep production in Chile is based primarily on natural prairie grass, presenting wide seasonal

Received: July 27, 2015. Accepted June 7, 2016.

Corresponding author:pperez@uchile.cl and annual fluctuations in nutritive quantity and quality (Pérez et al., 2002; Pérez et al., 2007). Supplementation with common feeds is not suitable because of the relatively high price of grains. The use of an available agro-industrial byproduct could reduce the impact of waste production and 
provide a low-cost animal feed alternative (Beken and Sahin, 2011), reducing the dependence on grains that are used for human consumption. Among the agricultural by-products eligible for animal feed, wastes from olive oil production, such as olive cake (OC), present a possible feed option. Olive cake is defined as the mixture of the olive juice and olive-pomace that is obtained from the oil extraction process by a two-phase decantation system. The use of OC as a feed could potentially result in a healthier fatty acids profile in animals (Molina and Yañez, 2007; Vera et al., 2009). Olive plantations have experienced high growth in the region under study; therefore, the by-product availability from olives produced in this region is growing (Chileoliva, 2011). In addition, sheep production is the predominant animal production activity in this region. The aim of this study was to evaluate the effect of feeding increased levels of olive cake in complete diets on the main carcass traits of lambs.

\section{Material and methods}

This research was conducted at the Experimental Center Hidango ( $34^{\circ} 06^{\prime} \mathrm{S} ; 71^{\circ} 47^{\prime} \mathrm{O}$ ) from Instituto de Investigaciones Agropecuarias (INIA) and the Faculty of Veterinarian and Livestock Sciences of the Universidad de Chile (33 35' 59.787' S; $70^{\circ}$ 37' 37.576”' O). Forty Suffolk Down male lambs, with a mean initial age of $75.8 \pm 7.4$ days and an initial body weight of $24.5 \pm 3.1 \mathrm{~kg}$ were randomly assigned to one of the following five dietary treatments: unweaned lambs fed in natural prairies alongside their mothers (GT) (a usual practice for farm sheep); control diet (CD) of alfalfa hay, maize grain, molasses, soybean meal, bicarbonate and mineral salts (Table 1); dehydrated olive cake (DOC) replacing $16 \%$ of the $\mathrm{CD}\left(\mathrm{TA}_{16}\right)$; DOC replacing $32 \%$ of the $\mathrm{CD}\left(\mathrm{TA}_{32}\right)$; and $\mathrm{DOC}$ replacing $48 \%$ of the $\mathrm{CD}\left(\mathrm{TA}_{48}\right)$. The Control diet, $\mathrm{TA}_{16}, \mathrm{TA}_{32}$ and $\mathrm{TA}_{48}$ were isoenergetic and isoproteic (2.5 Mcal ME $\mathrm{kg}^{-1} \mathrm{DM}$ and $140 \mathrm{~g}$ of crude protein $\mathrm{kg}^{-1} \mathrm{DM}$ ), and the offered feed met the maintenance and growth requirements, providing an average daily gain of $300 \mathrm{~g} \cdot \mathrm{d}^{-1}(\mathrm{NRC}$, 2007). The lambs were fed in individual cages. The lambs in the GT group grazed a pasture composed of Hypochaeris radicata (33\%), Trifolium glomeratum (21\%), Bromus hordeaceus (13\%), Vulpia bromoides (8\%), Hordeum berteroanum (6\%), Lolium rigidum (5\%), and traces of other species associated with Acacia caven. During an 8-day adaptation period, the treatment diets were gradually included along with alfalfa hay. The experimental period lasted 47 days. The lambs were weighed every 7 days prior to the morning feeding.

At the end of the experimental period, the lambs were transported to a commercial slaughterhouse

Table 1. Composition of the complete experimental rations with increased levels of dehydrated olive cake (fresh basis, g).

\begin{tabular}{lcccc}
\hline & \multicolumn{3}{c}{ Dietary treatments } \\
\cline { 2 - 5 } Ingredients & $\mathrm{CD}$ & $\mathrm{TA}_{16}$ & $\mathrm{TA}_{32}$ & $\mathrm{TA}_{48}$ \\
\hline Alfalfa hay & 570 & 420 & 295 & 150 \\
Corn grain & 545 & 455 & 370 & 285 \\
Dehydrated olive cake & 0 & 210 & 400 & 600 \\
Molasses & 25 & 25 & 25 & 25 \\
Soybean meal & 100 & 130 & 150 & 180 \\
Bicarbonate & 25 & 25 & 25 & 25 \\
Mineral salts & 6 & 6 & 6 & 6 \\
Total (g/animal/day) & 1240 & 1240 & 1240 & 1240 \\
\hline
\end{tabular}

CD: Control diet.

$\mathrm{TA}_{16 \text { : }}$ control diet replaced with $16 \%$ of dehydrated olive cake.

$\mathrm{TA}_{32:}$ control diet replaced with $32 \%$ of dehydrated olive cake.

$\mathrm{TA}_{48:}$ control diet replaced with $48 \%$ of dehydrated olive cake. 
and fasted (only water was available) for $12 \mathrm{~h}$ prior to slaughter. After weighing (LWS), the lambs were electrically stunned and slaughtered according to standard commercial procedures. The weight of the hot carcass (HCW), blood, kidney and kidney fat, feet (cuts at tarsal - metatarsal and carpal - metacarpal articulations), hide, full and empty gastrointestinal tracts, liver, heart, lungs (including trachea) and head (cut at the occipital - atlantoaxial articulation) were determined according to procedures previously described (Pérez et al., 2002; Pérez et al., 2007). The empty body weight (EBW) was calculated by subtracting the weight of the gastrointestinal contents (full minus empty gastrointestinal tract) from the LWS (Pérez et al., 2002; Pérez et al., 2007; Ekiz et al., 2013). Carcass yield (CY) was calculated as the hot carcass weight ( $\mathrm{HCW}$ ) divided by the LWS, and the real dressing percentage (RDP) was calculated as the HCW divided by the EBW (Velasco et al., 2000; Pérez et al., 2007). Two hours after slaughter, the carcasses were halved longitudinally with a band saw. Each half carcass $(\mathrm{HC})$ was cut between the $12^{\text {th }}$ and $13^{\text {th }}$ ribs. Fat depth (BFT) and rib eye area (REA) were measured after cutting. The BFT was measured over the cut surface of the Longissimus thoracis et lumborum muscle at the level of the $12^{\text {th }} \mathrm{rib}$ with a ruler (Pérez et al., 2002). The REA was measured using an $\mathrm{LI}-\mathrm{COR}$ portable area meter (LI-300 A) after tracing the transverse section of the eye muscle (Longissimus muscle) at the 12/13 ribs position (Dhanda et al., 2003; Pérez et al., 2007). The HCs were split into joints (chops, leg, thorax, shoulder and neck) according to the Chilean standard jointing procedure for lambs (INN, 2000; Pérez et al., 2007). The legs and shoulders from the left half of each carcass were packed in polyethylene bags, frozen at $-25^{\circ} \mathrm{C}$ and dissected 1 to 2 months later, as described by Cuthbertson et al. (1972). From the dissections, the following four groups of tissues were obtained: muscle, total fat (subcutaneous and intermuscular), bone and residues (lymphatic ganglia, large blood vessel and nerves, and tendons and joints capsules) (Ekiz et al., 2013) and the shrink losses were measured.
Each component was weighed using a balance with a $0.05 \mathrm{~g}$ sensitivity. The shrink losses were estimated as the differences between the initial and final weights of the anatomy pieces. These data were used to calculate the percentage of the tissue components of the shoulder and leg joint.

A completely random design for the treatment variables was conducted using a one-way analysis of variance, and significant differences between the groups were detected by Tukey-Kramer tests (Kaps and Lamberson, 2009). The data were expressed as the means and standard deviation. The mathematical model used was $\mathrm{Y}_{\mathrm{ij}}=\mu+\mathrm{T}_{\mathrm{i}}+$ $E_{i j}$, where $Y_{i j}$ was the observation $i$ of the treatment $j, \mu$ was the overall mean, $T_{j}$ was the fixed effect of treatment $i$ and $\varepsilon_{\mathrm{ij}}$ was the random error with a mean of 0 and a variance of $\sigma^{2}$. Significant differences were accepted at $\mathrm{P} \leq 0.05$.

\section{Results and discussion}

\section{Main carcass traits}

The results obtained for the main carcass traits are presented in Table 2. The LWS, HCW, CCW, EBW and KKCF were not significantly different $(\mathrm{P}>0.05)$ among the treatment groups. There were significant differences $(\mathrm{P} \leq 0.05)$ in $\mathrm{CY}$ between the $\mathrm{CD}$ and GT groups therefore, the olive cake level did not affect this yield. For RDP, $\mathrm{TA}_{48}$ was not significantly different $(\mathrm{P}>0.05)$ among all treatments, while the GT group presented significantly higher values $(\mathrm{P} \leq 0.05)$ than the $\mathrm{CD}$ group for $\mathrm{TA}_{16}$ and $\mathrm{TA}_{32}$.

The results obtained for $\mathrm{CY}$ were similar to those reported by Owaimer et al. (2004), who did not find any effect from the inclusion of olive cake on $\mathrm{CY}$ at an inclusion level of $12 \%$. In regard to the other carcass traits, Mioč et al. (2007) found that lambs receiving the highest olive cake diet (30\%) presented lower HCW and carcass yield than those fed the control diet or a diet with $15 \%$ of olive cake. Aboayasha et al. (1982), Belibasakis (1985) 
Table 2. Effect of the dietary treatments with increased levels of dehydrated olive cake on the main carcass traits of Suffolk Down lambs. (mean \pm standard deviation).

\begin{tabular}{llcccc}
\hline & \multicolumn{5}{c}{ Treatment } \\
\cline { 2 - 6 } \multicolumn{1}{c}{ Variable } & \multicolumn{1}{c}{$\mathrm{GT}$} & \multicolumn{1}{c}{$\mathrm{CD}$} & \multicolumn{1}{c}{$\mathrm{TA}_{16}$} & \multicolumn{1}{c}{$\mathrm{TA}_{32}$} & $\mathrm{TA}_{48}$ \\
\hline LWS $(\mathrm{kg})$ & $34.45 \pm 2.19$ & $31.75 \pm 3.23$ & $32.58 \pm 2.68$ & $32.45 \pm 2.13$ & $31.59 \pm 2.34$ \\
HCW (kg) & $17.95 \pm 1.47$ & $15.72 \pm 1.55$ & $16.48 \pm 1.90$ & $16.34 \pm 1.12$ & $16.11 \pm 1.69$ \\
CCW (kg) & $17.44 \pm 1.41$ & $15.26 \pm 1.52$ & $16.01 \pm 1.83$ & $15.83 \pm 1.12$ & $15.60 \pm 1.56$ \\
EBW (kg) & $30.67 \pm 1.98$ & $27.91 \pm 2.71$ & $29.22 \pm 2.88$ & $29.08 \pm 1.74$ & $27.94 \pm 2.21$ \\
CY (\%) & $52.06 \pm 1.53 \mathrm{~b}$ & $49.53 \pm 1.51 \mathrm{a}$ & $50.48 \pm 2.25 \mathrm{ab}$ & $50.36 \pm 1.27 \mathrm{ab}$ & $50.91 \pm 1.89 \mathrm{ab}$ \\
RDP $(\%)$ & $58.48 \pm 1.31 \mathrm{~b}$ & $56.31 \pm 1.40 \mathrm{a}$ & $56.32 \pm 1.59 \mathrm{a}$ & $56.17 \pm 0.82 \mathrm{a}$ & $57.57 \pm 2.02 \mathrm{ab}$ \\
REA (cm $)$ & $18.23 \pm 2.28 \mathrm{~b}$ & $17.71 \pm 2.00 \mathrm{ab}$ & $18.35 \pm 2.13 \mathrm{~b}$ & $15.67 \pm 1.86 \mathrm{a}$ & $15.66 \pm 2.03 \mathrm{a}$ \\
BFT (mm) & $1.01 \pm 0.22 \mathrm{a}$ & $1.25 \pm 0.14 \mathrm{ab}$ & $1.49 \pm 0.27 \mathrm{~b}$ & $1.50 \pm 0.31 \mathrm{~b}$ & $1.30 \pm 0.16 \mathrm{ab}$ \\
KKCF $(\%)$ & $0.45 \pm 0.23$ & $0.33 \pm 0.08$ & $0.48 \pm 0.17$ & $0.49 \pm 0.11$ & $0.53 \pm 0.12$ \\
\hline
\end{tabular}

Different letters (Tukey test) in the same row indicate significant differences among groups $(\mathrm{P} \leq 0.05)$.

GT: natural pasture, $\mathrm{CD}$ : control diet and, $\mathrm{TA}_{16}, \mathrm{TA}_{32}$ and $\mathrm{TA}_{48 ;} \mathrm{CD}$ with increased dehydrated olive cake amounts: 16,32 and $48 \%$, respectively.

LWS: live weight at sacrifice, $\mathrm{HCW}$ : hot carcass weight, $\mathrm{CCW}$ : cold carcass weight, EBW: empty body weight, CY: carcass yield, RDP: real dressing percentage, REA: rib eye area, BFT: back fat thickness, KKCF: renal pelvic fat weight

and Abo Omar and Gavoret (1995) included olive cake in levels of 20 to $25 \%$ and did not find any negative effects on body weight; while Owaimer et al. (2004) found no effect on the hot carcass weight when a $12 \%$ olive cake diet was fed. According to the results of our study, the levels of olive cake reached $48 \%$ yet exhibited no effects on the live weight and the HCW of the lambs.

The differences in carcass traits observed between the GT and TA groups can be attributed to other possible factors, such as the weaning of the lambs that were confined during the study $\left(\mathrm{TA}_{16}, \mathrm{TA}_{32}\right.$, $\mathrm{TA}_{48}$ and CD). Vergara et al. (1993) and Cañeque et al. (1998) found higher commercial yield in lambs staying with their mothers until they were slaughtered, which was similar to the present results. Nevertheless, they did not find any differences in the real yield. Meanwhile, Cañeque et al. (1998) obtained higher cold and hot carcass weights and higher empty live weight in suckling lambs, which was similar to the results from the current study, although their differences were not significant.

On the other hand, there were no differences in REA between the GT and $\mathrm{TA}_{16}$ treatment groups with means that were significantly greater for this trait $(\mathrm{P} \leq 0.05)$ compared to the $\mathrm{TA}_{32}$ and
$\mathrm{TA}_{48}$ groups. The $\mathrm{CD}$ value was not significantly different among the treatment groups. The treatments with a higher inclusion of DOC exhibited smaller REA values. Owaimer et al. (2004) found a significant decrease in REA when lambs were fed a complete diet that included $12 \%$ olive cake.

For BFT, the GT group showed a significantly lower average than the $\mathrm{TA}_{16}$ and $\mathrm{TA}_{32} \mathrm{~g}$ groups $(\mathrm{P} \leq 0.05)$. In contrast, $\mathrm{TA}_{48}$ and $\mathrm{CD}$ were not significantly different $(\mathrm{P}>0.05)$ from the other treatment groups. These values were similar to the results obtained by Borton et al. (2005) and Shingfield et al. (2012), who found differences among lambs fed forage and concentrate diets; lambs fed a forage-based diet exhibited a lower amount of back fat. However, Owaimer et al. (2004) reported that the BFT was significantly lower $(\mathrm{P} \leq 0.05)$ in the carcasses of lambs fed $12 \%$ olive cake than in control animals fed complete diets.

\section{Body components}

The values obtained for the body components are presented in Table 3. Only the hide, blood, empty digestive tract and tongue were affected by the $\operatorname{diet}(\mathrm{P} \leq 0.05)$. Hide was statistically greater in the $\mathrm{TA}_{16}$ and $\mathrm{CD}$ groups than in the $\mathrm{TA}_{48}$ group. 
Table 3. Effect of the dietary treatments with increased levels of dehydrated olive cake on the body components on the empty live weight of Suffolk Down lambs (mean \pm standard deviation).

\begin{tabular}{llllll}
\hline & \multicolumn{5}{c}{ Treatment } \\
\cline { 2 - 6 } Component (\%) & GT & $\mathrm{CD}$ & $\mathrm{TA}_{16}$ & $\mathrm{TA}_{32}$ & $\mathrm{TA}_{48}$ \\
\hline Hide & $11.09 \pm 0.40 \mathrm{ab}$ & $11.52 \pm 0.85 \mathrm{~b}$ & $11.46 \pm 0.87 \mathrm{~b}$ & $11.08 \pm 0.37 \mathrm{ab}$ & $10.19 \pm 0.73 \mathrm{a}$ \\
Blood & $4.91 \pm 0.58 \mathrm{ab}$ & $5.58 \pm 0.45 \mathrm{~b}$ & $4.84 \pm 0.58 \mathrm{a}$ & $5.14 \pm 0.42 \mathrm{ab}$ & $5.17 \pm 0.46 \mathrm{ab}$ \\
Feet & $2.47 \pm 0.17$ & $2.36 \pm 0.16$ & $2.33 \pm 0.16$ & $2.39 \pm 0.12$ & $2.41 \pm 0.10$ \\
Head & $4.18 \pm 0.24$ & $4.15 \pm 0.17$ & $4.19 \pm 0.31$ & $4.34 \pm 0.17$ & $4.24 \pm 0.24$ \\
Lung +trachea & $2.35 \pm 0.27$ & $2.25 \pm 0.15$ & $2.36 \pm 0.18$ & $2.26 \pm 0.08$ & $2.28 \pm 0.15$ \\
Heart & $0.53 \pm 0.05$ & $0.53 \pm 0.07$ & $0.51 \pm 0.05$ & $0.58 \pm 0.08$ & $0.53 \pm 0.05$ \\
Liver & $1.81 \pm 0.10$ & $1.81 \pm 0.10$ & $1.83 \pm 0.12$ & $1.86 \pm 0.09$ & $1.86 \pm 0.19$ \\
Spleen & $0.18 \pm 0.03$ & $0.19 \pm 0.03$ & $018 \pm 0.03$ & $0.20 \pm 0.03$ & $0.19 \pm 0.04$ \\
Penis & $0.15 \pm 0.02$ & $0.15 \pm 0.03$ & $0.14 \pm 0.02$ & $0.12 \pm 0.02$ & $0.13 \pm 0.02$ \\
Testicles & $0.71 \pm 0.12$ & $0.69 \pm 0.18$ & $0.69 \pm 0.07$ & $0.85 \pm 0.27$ & $0.72 \pm 0.15$ \\
Empty digestive tract & $9.64 \pm 1.02 \mathrm{a}$ & $10.86 \pm 0.41 \mathrm{~b}$ & $10.26 \pm 0.12 \mathrm{ab}$ & $10.50 \pm 0.46 \mathrm{ab}$ & $10.58 \pm 0.65 \mathrm{ab}$ \\
Kidneys & $0.35 \pm 0.02$ & $0.34 \pm 0.02$ & $0.35 \pm 0.03$ & $0.37 \pm 0.03$ & $0.38 \pm 0.04$ \\
Tongue & $0.26 \pm 0.02 \mathrm{a}$ & $0.27 \pm 0.06 \mathrm{a}$ & $0.46 \pm 0.10 \mathrm{~b}$ & $0.48 \pm 0.05 \mathrm{~b}$ & $0.68 \pm 0.06 \mathrm{~b}$ \\
\hline
\end{tabular}

GT: natural pasture, $\mathrm{CD}$ : control diet and, $\mathrm{TA}_{16}, \mathrm{TA}_{32}$ and $\mathrm{TA}_{48} \mathrm{CD}$ with increased dehydrated olive cake amounts: 16,32 and $48 \%$, respectively.

Different letters (Tukey test) in the same row indicate significant differences among groups $(\mathrm{P} \leq 0.05)$.

The result for blood weight was significantly lower in the $\mathrm{TA}_{16}$ group than in the $\mathrm{CD}$ group $(\mathrm{P} \leq 0.05)$; however, no other significant differences were observed among the treatment groups $(\mathrm{P}>0.05)$.

Regarding the empty digestive tract weight, the GT group was significantly different from the CD group, while the other treatments exhibited intermediary values. For tongue, the GT and CD treatment groups exhibited lower values than the other treatment groups, but the differences were not significant $(\mathrm{P}>0.05)$; There is no logical explanation for this result.

Our results were not in agreement with those reported by Mioč et al. (2007), who reported lower weights for the liver, hide and legs and higher weights for the stomach and intestines $(\mathrm{P} \leq 0.05)$ in lambs fed a diet containing $30 \%$ olive cake for 50 days. Similarly, Mioč et al. (2007) did not find any differences in lung and heart weights as a result of olive cake addition.

The differences observed for the empty digestive tract were similar to those reported by Cañeque et al. (1998), who obtained higher values for that trait in weaned lambs that remained with their mothers until slaughter.

\section{Commercial joints}

The results of the commercial joints are presented in Table 4. All of the variables were affected by the diet. The values obtained and the importance of the different joints were similar to the descriptions by Pérez et al. (2007) in four lamb genotypes slaughtered at 10 and $15 \mathrm{~kg}$ live weight, using the same quartering methodology. Generally, the carcass joints percentages were difficult to compare because of the absence of a universal quartering system and remarkable differences even within different regions in the same country.

\section{Tissue composition of shoulder and leg}

The tissue compositions of the shoulder and leg joints are presented in Table 5. There were no significant differences $(\mathrm{P}>0.05)$ among the 
Table 4. Effect of the dietary treatments with increased levels of dehydrated olive cake on the commercial carcass joints percentage on the left hemichannel from Suffolk Down lambs (mean \pm standard deviation).

\begin{tabular}{llllll}
\hline & \multicolumn{5}{c}{ Treatment } \\
\cline { 2 - 6 } Joints (\%) & GT & $\mathrm{CD}$ & $\mathrm{TA}_{16}$ & $\mathrm{TA}_{32}$ & $\mathrm{TA}_{48}$ \\
\hline Leg & $35.26 \pm 3.76$ & $34.68 \pm 2.26$ & $35.27 \pm 1.69$ & $36.06 \pm 3.75$ & $35.44 \pm 4.24$ \\
Shoulder & $20.16 \pm 2.29$ & $19.78 \pm 1.10$ & $20.01 \pm 1.78$ & $21.42 \pm 2.04$ & $20.26 \pm 2.35$ \\
Chops & $18.77 \pm 3.15$ & $18.41 \pm 2.09$ & $18.30 \pm 1.36$ & $17.79 \pm 3.18$ & $18.12 \pm 2.28$ \\
Rib & $18.86 \pm 1.03$ & $18.66 \pm 1.72$ & $20.64 \pm 2.65$ & $19.61 \pm 2.53$ & $19.60 \pm 3.17$ \\
Neck & $7.36 \pm 1.35$ & $6.98 \pm 0.71$ & $7.13 \pm 0.76$ & $6.30 \pm 0.55$ & $6.83 \pm 0.61$ \\
Tail & $0.81 \pm 0.19$ & $0.84 \pm 0.15$ & $0.90 \pm 0.13$ & $0.86 \pm 0.14$ & $0.92 \pm 0.14$ \\
\hline
\end{tabular}

GT: natural pasture, $\mathrm{CD}$ : control diet and, $\mathrm{TA}_{16}, \mathrm{TA}_{32}$ and $\mathrm{TA}_{48} \mathrm{CD}$ with increased dehydrated olive cake amounts: 16,32 y $48 \%$, respectively.

Table 5. Effect of the dietary treatments with increased levels of dehydrated olive cake on the different body component proportions of the shoulder and leg cuts from Suffolk Down lambs (mean \pm standard deviation).

\begin{tabular}{|c|c|c|c|c|c|}
\hline \multicolumn{6}{|c|}{ Treatment } \\
\hline Tissue $(\%)$ & GT & $\mathrm{CD}$ & $\mathrm{TA}_{16}$ & $\mathrm{TA}_{32}$ & $\mathrm{TA}_{48}$ \\
\hline \multicolumn{6}{|l|}{ Shoulder } \\
\hline Muscle & $56.46 \pm 4.96$ & $54.19 \pm 2.12$ & $54.76 \pm 2$ & $53.41 \pm 1.38$ & $54.07 \pm 2.47$ \\
\hline Bone & $20.50 \pm 1.25$ & $21.15 \pm 1.84$ & $20.63 \pm 1.91$ & $19.94 \pm 0.84$ & $20.15 \pm 0.88$ \\
\hline Cover fat & $8.69 \pm 3.77$ & $8.57 \pm 4.32$ & $9.21 \pm 2.15$ & $11.15 \pm 1.92$ & $11.01 \pm 2.09$ \\
\hline IM Fat & $4.64 \pm 2.26$ & $6.09 \pm 2.66$ & $5.66 \pm 2.57$ & $6.25 \pm 2.60$ & $5.65 \pm 3.01$ \\
\hline T Fat & $13.33 \pm 4.04$ & $14.66 \pm 3.96$ & $14.82 \pm 2.96$ & $17.39 \pm 2.12$ & $16.66 \pm 3.86$ \\
\hline Residues & $6.91 \pm 1.62$ & $7.35 \pm 1.43$ & $7.49 \pm 1.18$ & $6.83 \pm 1.12$ & $6.99 \pm 1.31$ \\
\hline Losses & $2.80 \pm 1.84$ & $2.64 \pm 1.11$ & $2.29 \pm 0.82$ & $2.42 \pm 0.40$ & $2.14 \pm 0.59$ \\
\hline \multicolumn{6}{|l|}{ Ratios } \\
\hline Muscle/fat & $4.65 \pm 1.58$ & $3.93 \pm 1.02$ & $3.85 \pm 0.92$ & $3.12 \pm 0.46$ & $3.43 \pm 0.91$ \\
\hline Muscle/bone & $2.76 \pm 0.26$ & $2.58 \pm 0.19$ & $2.68 \pm 0.29$ & $2.68 \pm 0.15$ & $2.68 \pm 0.09$ \\
\hline Muscle+fat/bone & $3.42 \pm 0.23$ & $3.29 \pm 0.42$ & $3.41 \pm 0.45$ & $3.56 \pm 0.21$ & $3.52 \pm 0.24$ \\
\hline \multicolumn{6}{|l|}{ Leg } \\
\hline Muscles & $61.53 \pm 2.85$ & $59.17 \pm 2.03$ & $56.64 \pm 5.77$ & $58.95 \pm 3.28$ & $58.55 \pm 2.58$ \\
\hline Bone & $19.01 \pm 1.66$ & $20.61 \pm 1.28$ & $20.44 \pm 2.06$ & $19.80 \pm 0.77$ & $19.92 \pm 0.93$ \\
\hline Cover fat & $7.08 \pm 2.20$ & $7.48 \pm 2.65$ & $7.92 \pm 1.67$ & $8.46 \pm 0.96$ & $8.45 \pm 2.05$ \\
\hline IM Fat & $3.56 \pm 1.18$ & $4.57 \pm 1.15$ & $3.52 \pm 0.89$ & $4.07 \pm 1.49$ & $5.52 \pm 1.98$ \\
\hline T Fat & $10.29 \pm 3.02$ & $12.05 \pm 2.66$ & $11.45 \pm 2.21$ & $12.53 \pm 1.21$ & $13.34 \pm 3.91$ \\
\hline Residues & $6.19 \pm 1.80$ & $6.47 \pm 0.82$ & $6.63 \pm 0.94$ & $6.72 \pm 1.67$ & $6.02 \pm 0.85$ \\
\hline Losses & $2.63 \pm 0.72$ & $2.32 \pm 0.90$ & $2.31 \pm 0.83$ & $2.44 \pm 0.80$ & $2.14 \pm 0.49$ \\
\hline \multicolumn{6}{|l|}{ Ratios } \\
\hline Muscle/fat & $6.49 \pm 2.04$ & $5.08 \pm 1.19$ & $5.34 \pm 1.07$ & $4.57 \pm 0.71$ & $4.81 \pm 1.56$ \\
\hline Muscle/bone & $3.27 \pm 0.41$ & $2.85 \pm 0.20$ & $2.92 \pm 0.33$ & $2.86 \pm 0.31$ & $2.97 \pm 0.22$ \\
\hline Muscle+fat/bone & $3.82 \pm 0.56$ & $3.44 \pm 0.28$ & $3.50 \pm 0.47$ & $3.50 \pm 0.31$ & $3.64 \pm 0.25$ \\
\hline
\end{tabular}

GT: natural pasture, $\mathrm{CD}$ : control diet and, $\mathrm{TA}_{16}, \mathrm{TA}_{32}$ and $\mathrm{TA}_{48} \mathrm{CD}$ with increased dehydrated olive cake amounts: 16,32 and $48 \%$, respectively.

IM Fat: intramuscular fat, T Fat: total fat. 
treatment groups for any of the studied variables or the tissue ratios. These results were in agreement with the report by Pérez et al. (2007) on suckling lambs from different genotypes that were slaughtered at 10 and $15 \mathrm{~kg}$ of live body weight. The tissue composition of the leg showed a better composition because it had a higher muscle percentage and a lower fat percentage than the shoulder.

\section{Ratios among the tissue components}

The results of this study are in agreement with Velasco et al. (1998) and Pérez et al. (1998), who did not find significant differences in the muscle/ bone and muscle/fat ratio, respectively, among weaned animals that were confined and those that grazed alongside their mothers until slaughter. Conversely, Owaimer et al. (2004) did not find any differences in the muscle/bone ratio of the entire carcass of lambs fed rations containing $12 \%$ of olive cake.

The addition of DOC to the diet did not affect the lamb carcass quality at the levels used in this work.

\section{Acknowledgements}

This research was funded by the Fundación para la Innovación Agraria (FIA). Chile, Project PIC2005-IPO68.

\section{Resumen}

P. Pérez, F. Squella, C. Aguilar, M.J. Idalsoaga, R. Vera, M.S. Morales, M. Maino y J.I. Egaña. 2016. Uso de niveles incrementales de alperujo deshidratado de oliva en dietas de cordero como una alternativa para sistemas de producción a pastoreo en la zona de secano central de Chile. Efecto sobre las características de la canal en corderos Suffolk Down. Cien. Inv. Agr. 43(2):213-221. Se evaluó la inclusión de alperujo deshidratado de oliva (ADO) en la ración de corderos sobre las principales características de la canal, utilizando 40 corderos Suffolk Down (75,8 \pm 7,4 días de edad, 24,5 $\pm 3,1 \mathrm{~kg}$ peso vivo). ADO se incluyó en cuatro dietas: Dieta control con 0\% ADO (DC), DC con 16, 32 y 48\% ADO, más un grupo a pastoreo que se mantuvo con sus madres. Durante el ensayo (47 días), los corderos se mantuvieron en corrales individuales $\left(1,4 \mathrm{~m}^{2}\right)$. Los corderos fueron sacrificados a los $123 \pm 7$ días, y peso vivo promedio de $32,56 \pm 2,62 \mathrm{~kg}$. Al sacrificio se registró: peso vivo, peso de la canal caliente, peso de la canal fría, rendimiento comercial (RC), rendimiento verdadero de la canal (RV), peso de los componentes del cuerpo (sangre, piel, cabeza, piernas, el tracto digestivo lleno y vacío, y vísceras), área del ojo del lomo (AOL), espesor de grasa dorsal (EGD), peso de grasa perirenal y rendimiento de corte comercial (RCC). Adicionalmente, en espaldilla (E) y pierna (P) se estudiaron los componentes del tejido (CT) y sus proporciones (PT). El incremento de ADO en la dieta causó una disminución de RC, RV y AOL y un aumento de EGD $(\mathrm{P}<0,05)$. No se detectaron diferencias $(\mathrm{P}>0,05)$ en $\mathrm{RCC}$, ni en $\mathrm{CT}$ y PT de H y P. La adición de ADO a dietas de corderos, en los niveles utilizados en este trabajo, no afectó la calidad de la canal de cordero.

\section{References}

Aboayasha, A.M., F.Omar, and M.A. Razzaque. 1982. Use of olive cake supplemented with soybean in the rations of growing Barbary lambs. Libyan J. Agric. 11: 67-74.
Abo Omar, J., and L.Gavoret. 1995. Utilization of olive cake in fattening rations of Awassi lambs. Rev. Med. Vet. 146:273-276.

Beken, Y., and A. Dahin. 2011. The effect of prina 
(olive cake) feeding methods on growth performance and behavior of Awassi lambs. Int. J. Agric. Biol. 13: 423-426.

Belibasakis, N. 1985. Effect of olive cake pulp on the fattening lambs: 2 diets of low proportion of olive cake pulp. Ellenike Kteniatrike Hellenic Vet. Med. 28: 222-230.

Borton, R., S. Loerch, K. McClure, D. and Wulf, D. 2005. Comparison of characteristics of lambs fed concentrate of grazed on ryegrass to traditional or heavy slaughter weights. I. Production, carcass and organoleptic characteristics. J. Anim. Sci. 83: 679-685.

Cañeque, V., S. Lauzurica, C. Pérez, F. Huidobro, S. Velasco, J. Gayán, M.T. Díaz, J.L. Sancha, and M.A. Cantero. 1998. Efecto del sistema de destete en la calidad de la canal en corderos de raza Talaverana, sacrificados a dos pesos. Parámetros productivos al sacrificio. In: XXIII Jornadas Científicas Sociedad Española de Ovinotecnia y Caprinotecnia. Vitoria-Gastéiz, España. 1-3 de octubre de 1998. p. 113-116.

Chileoliva. 2011. Informe anual del mercado nacional de aceite de oliva-2010. Available online at: HTTP://www.2011.chileoliva.cl/files78/pdf Website accessed August 1, 2011). 19 pp.

Cuthbertson, A., G.Harrington, and R.J. Smith. 1972. Tissue separation to asses beef and lamb variation. Proc. Br. Soc. Anim. Prod. p. 113-122.

Dhanda, J.S., D.G. Taylor, and P.J. Murray. 2003. Part I. Growth, carcass and meats quality parameters of male goats: effects of genotype and liveweight at slaughter. Small. Rumin. Res. 50: 57-66.

Delfa, R., S. Tort, A. Bergua, F. Lahoz, R. Revilla, and M. Joy. 2005. Efecto del sistema de producción sobre el quinto cuarto de corderos Churro Tensino. In: XXX Jornadas Científicas y IX internacionales de la Sociedad Española de Ovinotecnia y Caprinotecnia. Granada, España. 28-30 de septiembre, 1 de octubre de 2005. p. 55-58.

Ekiz, B., G.Demirel, A. Yilmaz, M. Ozcan, H. Yalcintan, O. Kocak, and A. Altinel. 2013. Slaughter characteristics, carcass quality and fatty acid composition of lambs under four different production systems. Small. Rumin. Res. 114: 2634.
INN - Instituto Nacional de Normalización. 2000. Cortes de canales de ovinos. Norma Chilena NCH 1595 of. 2000. Santiago, Chile. 5 pp.

Kaps, M., and W. Lamberson. 2009. Biostatistics for Animal Science. $2^{\text {nd }}$ edition, CAB International, London,UK. 504 pp.

Mioč, B., V. Pavić, I. Vnuěc, Z. Prpić, A. Kostelić, and V. Sušić. 2007. Effect of olive cake on daily gain, carcass characteristics and chemical composition of lamb meat. Czech J. Anim. Sci. 52: 31-36.

Molina, E., and D. Yañez. 2007. Potential use of olive by-products in ruminant feeding: A review. Anim. Feed Sci. Technol. 147: 247-264.

NRC. - National Research Council. 2007. Nutrient requirement of small ruminants: sheeps, goats, cervids, and New World camelids. Pages 384. Committee on Animal Nutrition, Board on Agriculture and Natural Resources. National Research Council (NRC), Washington, D.C., USA.

Owaimer, A.N., M.S. Kraides, M. Al-saiady, S. Zahran, and M.A. Abouoheil. 2004. Effect of feeding olive cake in complete diet on performance and nutrient utilization of lambs. Asian-Aust. J. Anim. Sci. 17:491-496.

Pérez, P., M. Maino, M.S. Morales, C. Köbrich, C. Bardón, and J. Pokniak. 2007. Gender and slaughter weight effects on carcass quality traits of suckling lambs from four different genotypes. Small Rumin. Res: 70:124-130.

Pérez, P., M. Maino, G. Tomic, E. Mardones, and J. Pokniak. 2002. Carcass characteristics and meats quality of Suffolk Down suckling lambs. Small Rumin. Res. 44: 233-240.

Pérez, C., S. Lauzurica, F. Huidobro, V. Cañeque, S. Velasco, J. Gayán, C. Manzanares, M.T. Díaz, J.L. Sancha, and D. Gómez. 1998. Engorde de corderos Talaveranos en aprisco o en pastoreo: II Características de sus canales. In: XXIII Jornadas Científicas de la Sociedad Española de Ovinotecnia y Caprinotecnia. Vitoria-Gastéiz, España. 1-3 de octubre de 1998. p. 129-132.

Shingfield, K.J., M. Bonnet, and N.D. Scollan. 2012. Recent developments in altering the fatty acid composition of ruminant-derived foods. Animal: 7:s1, 132-162. 
Velasco, S., C. Pérez, V. Cañeque, F. Huidobro, S. Lauzurica, J. Gayan, M.T. Díaz, C. Manzanares, J.L. Sancha. 1998. Efecto del sistema de destete en la calidad de la canal en corderos de raza Talaverana, sacrificados a dos pesos. II. Características de la canal. In: XXIII Jornadas Científicas de la Sociedad Española de Ovinotecnia y Caprinotecnia. p. 117-121. Available online at: http:// www.seoc.eu/site/es/biblioteca-seoc (Website accessed: October 15, 2015).

Velasco, S., S. Lauzurica, V. Cañeque, C. Pérez, F. Huidobro, C. Manzanares, and M.T. Díaz. 2000. Carcass and meats quality of Talaverana breed suckling lambs in relation to gender and slaughter weight. Anim. Sci. 70: 253-263.
Vera, R., C. Aguilar, R. Lira, P. Toro, L. Barrales, I. Peña, F. Squella, P. Pérez, J. Quenaya, H. Yutronic, and I. Briones. 2009. Feeding dry olive cake modifies subcutaneous fat composition in lambs, noting cake resistance to degradation and peroxidation. Chilean J. Agric. Res. 69: 548-559.

Vergara, H., L. Gallego, and A. Molina.1993. Producción de carne de raza Manchega: I Rendimiento de la canal y componentes del quinto cuarto. In: XVIII Jornadas Científicas de la Sociedad Española de Ovinotecnia y Caprinotecnia. Albacete, España. 18-19 de septiembre de 1993. p. 150-153. 
